\title{
Efektivitas Model Pembelajaran Problem Based Learning dan Inquiry terhadap Hasil Belajar Instalasi Tenaga Listrik
}

\author{
Anita Kurniawati Hartina ${ }^{1]}$, Endi Permata ${ }^{2]}$, Mohammad Fatkhurrokhman ${ }^{3]}$ \\ Universitas Sultan Ageng Tirtayasa \\ E-mail: ${ }^{1]}$ anitakurniawatihartina@yahoo.com \\ ${ }^{2]}$ endipermata@untirta.ac.id \\ ${ }^{3]}$ fatkhur0404@untirta.ac.id
}

\begin{abstract}
Abstrak
Dilakukannya penelitian ini meliputi latar belakang berdasarkan rendahnya hasil belajar siswa untuk mata pelajaran instalasi tenaga listrik kelas XII program keahlian Teknik Ketenagalistrikan di SMK PGRI 1 Kota Serang. Tujuan atas pelaksanaan penelitian ini ialah untuk mengetahui: (1) Bagaimana efektivitas model pembelajaran problem based learning dibandingkan model konvensional pada hasil belajar instalasi tenaga listrik siswa, (2) Bagaimana efektivitas model pembelajaran inquiry dibandingkan model konvensional pada hasil belajar instalasi tenaga listrik siswa, (3) Bagaimana perbedaan efektivitas model pembelajaran problem based learning, model pembelajaran inquiry dan model konvensional terhadap hasil belajar instalasi tenaga listrik siswa. Pada kegiatan penelitian ini digunakannya metode penelitian quasi eksperiment pada desain penelitian non equivalent control group design. Instrumen pengumpul data untuk digunakan dalam penelitian ini adalah soal tes hasil belajar instalasi tenaga listrik (pretest dan posttest). Teknik analisis data pada penelitian ini memakai uji Anova Satu Jalur. Uji beda rata-rata dihasilkan nilai sig. $<0,05$ yakni menunjukkan bahwa adanya perbedaan rata-rata dari ketiga kelompok. Efektivitas model pembelajaran Inquiry lebih efektif untuk meningkatkan hasil belajar siswa, diperlihatkan dengan nilai effect size sebesar 0,97 sedangan untuk model Problem Based Learning sebesar 0,33. Berdasarkan pada hasil tersebut bisa disimpulkan untuk model pembelajaran Inquiry lebih efektif dibandingkan model konvensional terhadap hasil belajar instalasi tenaga listrik siswa, model Problem Based Learning lebih efektif dibandingkan model konvensional terhadap hasil belajar instalasi tenaga listrik siswa, dan model Inquiry lebih efektif dibandingkan model
\end{abstract} Problem Based Learning terhadap hasil belajar instalasi tenaga listrik siswa.

Kata Kunci: Problem Based Learning, Inquiry, Hasil Belajar

\section{Effectiveness of Problem Based Learning and Inquiry Learning Model for Learning Results of Electricity Installation}

\footnotetext{
Abstract

The conduct of this study includes a background based on the low student learning outcomes for subjects of electrical installation in class XII of the Electricity Engineering
} 
expertise program at SMK PGRI 1 Serang City. The purpose of the implementation of this research is to find out: (1) How the effectiveness of the learning model of problem based learning compared to conventional models on learning outcomes of students' electricity installations, (2) How the effectiveness of inquiry learning models compared to conventional models on learning outcomes of student electrical installations, (3) What is the difference between the effectiveness of the problem based learning model, the inquiry learning model and the conventional model to the learning outcomes of students' electrical installations. In this research activity the quasi-experimental research method was used in the non equivalent control group design research design. Data collection instruments for use in this study were test results of learning outcomes for electric power installations (pretest and posttest). Data analysis techniques in this study used the One Way Anova test. The average difference test resulted in a value of sig. $<0.05$ which indicates that there were differences in the mean of the three groups. The effectiveness of Inquiry learning models is more effective to improve student learning outcomes, shown by the value of the effect size of 0.97 while the Problem Based Learning model of 0.33. Based on these results it can be concluded that the Inquiry learning model is more effective than the conventional model of learning outcomes of students' electrical installations, the Problem Based Learning model is more effective than the conventional model of learning outcomes of electrical power installation students, and the Inquiry model is more effective than the Problem Based Learning model on the learning outcomes of students' electrical power installations.

Keywords: Problem based learning, inquiry learning, learning outcomes

\section{PENDAHULUAN}

Pendidikan bisa dikatakan suatu tindakan yang digunakan untuk mencerdaskan bangsa dalam bentuk upaya sebagai memperluas pengetahuan rangka awal serta didasari atas nilainilai kehidupan sehingga bertujuan dalam membentuk nilai, sikap, serta perilaku sehingga akan tercapailah tujuan pendidikan nasional itu yang tercantum serta sesuai dengan ketentuan hukum yang berlaku di ketentuan Undang-Undang Dasar Negara Republik Indonesia pada alinea ke-4.

Sekolah ialah bagian pendidikan formal yang sejatinya wajib membekali generasi muda agar bisa menghadapi zaman yang terus berkembang sampai saat ini juga begitu kompleks. Pada pendidikan formal selain kualitas guru, kemampuan timbal balik antar guru dan siswa dikatakan unsur penting yang tidak dapat dipisahkan, yakni dengan kualitas interaksi guru terhadap siswa ialah sebagai tolak ukur pada suatu lembaga salah satunya pendidikan formal untuk mendidik generasi muda.

Sekolah Menengah Kejuruan (SMK) dikatakan lembaga pendidikan formal di tingkat menengah untuk membekali peserta didik agar memiliki keterampilan dan keahlian dibidang tertentu sebagai bentuk untuk mempersiapkan ketika masuk di dunia kerja kelak. SMK memiliki peran secara langsung mendukung pembangunan nasional, khususnya menyiapkan tenaga kerja yang handal, terampil dan terdidik dibutuhkan dunia industri. Sejalan tujuan tersebut, siswa SMK dibekali pengetahuan dan keterampilan pada 
jurusan masing-masing. (Rusman, 2017: 84).

Instalasi Tenaga Listrik merupakan salah satu mata pelajaran wajib yang harus diambil pada siswa kelas XII program keahlian teknik ketenagalistrikkan. Mata pelajaran instalasi tenaga listrik ini mengajarkan materi tentang bagaimana memahami, menerapkan serta menganalisis perencanaan sampai dengan pemasangan instalasi tenaga listrik sehingga nantinya akan memberikan keterampilan pada peserta didik memecahkan masalah pada kehidupan sehari-hari.

Namun di kelas XII program keahlian Teknik Ketenagalistrikan SMK PGRI 1 Kota Serang dalam proses pembelajarannya model pembelajaran digunakan guru belum mampu menciptakan kondisi pada kelas. Hal itu guru nyaman memakai model pembelajaran bersifat konvensional lebih terpusat kepada guru dalam proses pembelajarannya (teacher centered) sehingga peserta didik cenderung menjadi pasif hanya melihat juga mendengarkan penjelasan oleh guru. Untuk itu peneliti melakukan studi pendahuluan dengan memberikan angket kepada siswa kelas XII program keahlian Teknik Ketenagalistrikan SMK PGRI 1 Kota Serang untuk dapat benarbenar mengetahui permasalahan yang dialami oleh siswa.

Berdasarkan dari studi awal telah dilakukan dapat diketahui bahwa permasalahan di kelas XII program keahlian teknik ketenagalistrikkan SMK PGRI 1 Kota Serang adalah peserta didik kurang senang dalam mengemukakan pendapat, peserta didik cenderung kurang aktif bertanya ketika pembelajaran berlangsung di dalam kelas, peserta didik kurang menyukai metode pembelajaran ceramah, peserta didik kurang termotivasi dengan digunakannya metode ceramah saat proses belajar, dan guru sering melakukan metode pembelajaran ceramah yang seharusnya kegiatan praktik.

Permasalahan-permasalahan tersebut mengakibatkan peserta didik kurang dapat memahami materi pelajaran instalasi tenaga listrik dengan baik, yang mana menunjukan rata-rata hasil Penilaian Tengan Semester (PTS) yang kecil di bawah Kriteria Ketuntasan Minimal (KKM) sekolah yakni 78 . Kemudian permasalahan yang lain adalah masih digunakannya metode pembelajaran konvensional sehingga guru lebih aktif dalam menyampaikan materi juga siswa hanya memperhatikan penjelasan dari guru. Kegiatan pembelajaran hal itu membuat peserta didik menjadi lebih mudah merasa jenuh. Peserta didik akan lebih senang dan tertarik apabila proses pembelajaran Instalasi Tenaga Listrik dengan praktik langsung. Kurang senangnya peserta didik dengan pelajaran Instalasi Tenaga Listrik tersebut menyebabkan peserta didik pun seringkali terlambat datang ke sekolah.

Setelah mengetahui beberapa permasalahan di atas, dan juga melihat pentingnya mata pelajaran Instalasi Tenaga Listrik untuk kelas XII program keahlian Teknik Ketenagalistrikan perlu solusi serta tindak lanjut yang tepat memperbaiki hasil belajar siswa. Solusi dan tindak lanjut yang perlu dilakukan merubah cara pandang siswa mengenai mata pelajaran Instalasi Tenaga Listrik membosankan menjadi menyenangkan dengan menambah model pembelajaran agar pembelajaran tidak monoton dan memiliki variasi. Kemudian dengan memunculkan masalah nyata pada proses pembelajaran di kelas agar dapat meningkatkan kemampuan berfikir siswa untuk menuntaskan masalah juga meningkatkan keterampilan siswa 
dengan cara memakai model pembelajaran Problem Based Learning dan model pembelajaran Inquiry.

Efektivitas dalam inggris yaitu Effective artinya berhasil, tepat atau manjur. Sedangkan dalam arti lain efektivitas adalah suatu pengaruh yang diakibatkan dalam bentuk ditimbulkan dalam keberhasilan tindakan atau usaha, menjelaskan efektivitas akan tercapai tidaknya tujuan jika sudah direncanakan, tercantum dalam kamus besar bahasa indonesia (KBBI) (Lefrida, 2011). Efektivitas menunjukkan taraf tercapainya tujuan, usaha dikatakan efektif jika usaha itu mencapai tujuannya.

Efektivitas pembelajaran diartikan sebagai kegiatan saat pembelajaran berpengaruh pada kesukesan usaha serta tindakan terhadap hasil belajar peserta didik (Saregar, Latifah, \& Sari, 2016). Namun begitu pembelajaran efektif tidak hanya dilihat dari hasil belajar siswa, tetapi juga dilihat dari bagaimana guru memberi penjelasan yang baik, sikap disiplin, tekun, dan rasa senang ketika belajar dengan penuh semangat.

Menciptakan kondisi belajar secara efektif sangat penting dilakukan oleh seorang guru, kerena belajar secara efektif bisa membuat kemampuan siswa menjadi lebih meningkat sesuai dengan tujuan akan dicapai. Sehingga efektivitas belajaran dapat diartikan sebagai sejauh mana suatu pembelajaran mencapai tujuan direncanakan.

Belajar merupakan segala situasi dalam bentuk interaksi di sekitar siswa (Rusman, 2017:1). Selanjutnya, pembelajaran pada hakikatnya adalah kegiatan antar guru dan siswa yang terjalin interaksi baik langsung atau tidak langsung kemudian menggunakan media pembelajaran (Rusman, 2017: 84). Model pembelajaran pendapat Joyce \& Weil pada buku Rusman
(2016: 42) menjelaskan model pembelajaran adalah rencana digunakan dalam membuat kurikulum, membuat bahan-bahan pembelajaran serta membimbing pembelajaran di kelas.

Menurut Lahir, Ma'ruf, \& Tho'in (2017: 33) model pembelajaran adalah cara guru atau dosen dan peserta didik untuk melaksanakan proses pembelajaran pada tujuan diharapkan secara bersama-sama. Dari penjabaran kedua pendapat tadi diambil kesimpulan bahwa proses tingkah laku individu pada suatu rencana atau pola dari rancangan pembelajaran agar mencapai tujuan sehingga menghasilkan belajar yang diinginkan adalah model pembelajaran Model pembelajaran Problem Based Learning dikatakan pembelajaran dengan terpusat pada masalah (autentik)

bagi peserta didik untuk memotivasi, mengidentifikasi dan berpikir kritis dalam menuntaskan masalah juga sekaligus membangun pengetahuan benar-benar bermakna (Rusman, 2016: 241). Pembelajaran dengan berpusat di masalah artinya masalah menjadi tema, unit, atau isi fokus utama belajar (Awal \& Pardede, 2017). Bisa di simpulkan yakni rangkaian kegiatan pembelajaran agar berasumsi pada masalah nyata di kehidupan aktual siswa sehingga dapat berpikir kritis, mengidentifikasi dan memotivasi dalam menyelesaikan masalah juga menumbuhkan pengetahuan yang berarti serta bermakna bagi siswa untuk mengembangkan kemampuan siswa pada pemikiran berbasis kesalahan.

Inkuiri dalam inggris Inquiry,
dengan makna pertanyaan, pemeriksaan, penemuan, penyelidikan. Pendapat Sund \& Trowbridge (2011) inquiry diartikan sebagai kegiatan mendefinisikan dan menyelidiki masalah-masalah, merumuskan hipotesis, merancang eksperimen, 
menemukan data serta menggambarkan kesimpulan masalah-masalah. Tujuan model pembelajaran inquiry ialah memberikan siswa untuk membangun kecakapan intelektual yang terikat dengan berpikir reflektif.

Menurut Awg Kitot, Ahmad, \& Seman, (2011) model pembelajaran inquiry adalah pendekatan untuk pemecahan masalah berbasis inquiry dengan berbagai cara juga metode seperti studi eksperimen berdasarkan buku teks. Proses inquiry mengikuti proses menemukan serta mendapatkan informasi dalam suatu konsep, teori atau pertanyaan dan digunakan untuk melakukan penyelidikan tentang masalah. Kunandar dalam buku Shoimin (2014: 85) mengatakan pembelajaran inquiry yakni pembelajaran dimana siswa didorong belajar melalui keterlibatan aktif lewat konsep dan prinsip serta guru mendorong siswa memiliki pengalaman dan melakukan percobaan dapat siswa temukan lewat diri mereka sendiri. Selanjutnya, Wina dalam buku Shoimin (2014: 85) mengatakan pembelajaran inquiry adalah kegiatan belajar menitiberatkan kegiatan berpikir analitis dan kritis agar dipertanyakan. Inquiry adalah strategi pendidikan di mana siswa mengikuti metode dan praktik yang mirip dengan profesional ilmuwan dalam rangka membangun pengetahuan (Pedaste, et al., 2015).

Model pembelajaran Inquiry dikatakan pembelajaran dengan melibatkan kekuatan siswa akan mencari dan menyelidiki secara sistematis, kritis, logis, analitis, agar siswa bisa merumuskan sendiri hasil penemuannya dalam kondisi percaya diri. (Shoimin, 2014: 85). Proses pembelajaran inquiry dilakukan oleh peserta didik, instruktur atau guru berperan tidak lebih sebagai pelatih, pemandu, fasilitator, untuk membantu peserta didik tiba konsep pengetahuan yang benar (Zuliana, 2017). Bisa disimpulkan yakni kegiatan pembelajaran dengan melibatkan seluruh kemampuan siswa agar mencari dan menyelidiki secara sistemik, kritis, logis, dan analitis biar siswa bisa merumuskan konsep materi dari masalah yang ditemukan. Peran guru dalam model pembelajaran inquiry selain pembimbing dan pengarah, juga bisa sebagai sumber informasi. Guru juga mengurangi intervensi kegiatan siswa memecahkan masalah. Kedua pembelajaran ini tidak hanya menjelaskan pemahaman konsep, juga mendorong pengalaman belajar siswa mencari konsep-konsep ilmiah sehingga bisa memberikan pemahaman lebih mendalam, lebih lama diingat, lebih bermakna, dan dapat melatih kemampuan memecahkan masalah. Serta hasil yang akan didapatkan dalam belajar ini yakni hasil belajar (perubahan tingkah laku: kognitif, afektif dan psikomotorik) seusai proses pembelajaran.

Hasil belajar hakikatnya ialah berubahnya prilaku seseorang mencakup kemampuan kognitif, afektif, dan psikomotor sesudah mengikuti rangkaian kegiatan belajar mengajar. Pendidikan dan pengajaran dikatakan berhasil jika perubahan terlihat akibat dari belajar mengajar dialaminya berupa kegiatan ditempuhnya melalui program dan kegiatan dirancang dan dilaksanakan oleh guru pada pengajarannya.

Hasil belajar menunjukkan perubahan lebih baik, bermanfaat untuk: (a) menambah pengetahuan, (b) lebih memahami sesuatu belum dipahami, (c) lebih mengembangkan keterampilan, (d) memiliki pandangan baru atas sesuatu hal, (e) lebih menghargai sesuatu daripada sebelumnya. Ditarik kesimpulan yakni hasil belajar ialah 
perubahan diri siswa sehingga memiliki perubahan dari segi pegetahuan, sikap, dan keterampilan.

Berdasarkan permasalahan yang sudah dijabarkan peneliti tertarik melakukan penelitian dengan judul "Efektivitas Model Pembelajaran Problem Based Learning dan Inquiry terhadap Hasil Belajar pada Mata Pelajaran Instalasi Tenaga Listrik di Kelas XII Teknik Ketenagalistrikan SMK PGRI 1 Kota Serang". Hasil belajar penelitian ini untuk mengetahui signifikansi perbedaan tes hasil belajar ranah kognitif siswa, hal tersebut dikarenakan masih rendahnya hasil belajar siswa kelas XII pada mata pelajaran Instalasi Tenaga Listrik dalam ranah kognitifnya.

Setelah peneliti melakukan observasi dan melihat materi yang disajikan oleh guru terhadap siswa, maka didapatkan pada kompetensi dasar 3.15 dan 3.16 dengan pokok bahasan mengenai sistem busbar dan pelindung saluran kabel. Kompetensi dasar ini dipilih karena siswa sudah masuk dalam pembahasan materi ini, kemudian untuk kelengkapan alat dan bahan praktik sudah tersedia di sekolah. Penerapan materi ini yaitu siswa melakukan praktik pada sistem busbar di bangunan gedung dengan perencanaan awal membuat denah bangunan gedung bertingkat, menentukan komponen listrik yang digunakan, membuat rekapitulasi daya dan penghubungan sistem busbar ke dalam tiga tahapan (utama, main sub, sub). Penerapan pelindung saluran kabel pada saat pendistribusian kabel ke busbar.

\section{METODE}

Jenis penelitian dipakai ialah quasi eksperimental design, dimana peneliti memberi suatu perlakuan atau stimulasi kemudian melihat pengaruh yang diakibatkan dari perlakuan tersebut (Sudjana, 2017: 56). Desain penelitian dipakai yakni non equivalent control group design. Bentuk desain non equivalent control group design hampir sama dengan pretest posttest control group design, tetapi desain ini kelompok eksperimen maupun kelompok kontrol tidak dipilih secara random.

Tabel 1. Desain Penelitian

\begin{tabular}{llll}
\hline Kelas & Pretest & Treatment & Posttest \\
\hline Eksperimen 1 & $\mathrm{O}_{1}$ & $\mathrm{X}_{\mathrm{PBL}}$ & $\mathrm{O}_{2}$ \\
Eksperimen 2 & $\mathrm{O}_{3}$ & $\mathrm{X}_{\text {Inquiry }}$ & $\mathrm{O}_{4}$ \\
Kontrol & $\mathrm{O}_{5}$ & - & $\mathrm{O}_{6}$ \\
\hline
\end{tabular}

Keterangan:

$\mathrm{O}_{1} \quad=$ pretest kelas eksperimen pertama

$\mathrm{O}_{2} \quad=$ posttest kelas eksperimen pertama

$\mathrm{O}_{3} \quad=$ pretest kelas eksperimen kedua

$\mathrm{O}_{4} \quad=$ posttest kelas eksperimen kedua

$\mathrm{O}_{5} \quad=$ pretest kelas kontrol

$\mathrm{O}_{6} \quad=$ posttest kelas kontrol

$\mathrm{X}_{\mathrm{PBL}}=$ perlakuan dengan menggunakan model pembelajaran probem based learning

$\mathrm{X}_{\text {Inquiry }}=$ perlakuan dengan menggunakan model pembelajaran inquiry

= tanpa perlakuan

Pada desain penelitian tersebut diketahui penelitian memakai tiga kelompok kelas, dimana kelas pertama dikasih perlakuan model pembelajaran probem based learning, kelas kedua dikasih perlakuan model pembelajaran inquiry, sedangkan kelas ketiga tidak diberikan perlakuan apapun (Sugiyono, 2015: 110).

Penelitian dilakukan satu bulan. Waktu pelaksanaan penelitian dimulai pada tanggal 28 Oktober 2019 sampai dengan 30 November 2019 di SMK PGRI 1 Kota Serang program keahlian 
Teknik Ketenagalistrikan kelas XII. Sampel penelitian terdiri dari 3 kelas berjumlah 88 siswa. Instrumen pengumpul data digunakan dalam penelitian ini berbentuk soal tes hasil belajar instalasi tenaga listrik (pretest dan posttest). Teknik analisis data penelitian ini menggunakan uji Anova Satu Jalur.

\section{Uji Validitas}

Suatu instrumen dikatakan valid jika tingkat kevalidannya tinggi begitu pun sebaliknya. Pengujian validitas ini dilakukan untuk menguji setiap butir instrumen dilakukan yaitu validitas konstrak dan validitas isi (Sudjana N., 2017: 12). Untuk menentukan validitasnya peneliti menggunakan koefisien korelasi product moment dari Karl Pearson. Koefisien korelasi product moment dari Karl Pearson digunakan dalam mengetahui korelasi antara variabel prediktor (X) dan variabel kriterium (Y) yang akan dihitung koefisien korelasi (r) sebagai berikut:

$$
\mathrm{r}_{\mathrm{xy}}=\frac{N \sum X Y-\left(\sum X\right)\left(\sum Y\right)}{\sqrt{\left(N \sum X^{2}-\left(\sum X\right)^{2}\left(N \sum Y^{2}-\left(\sum Y^{2}\right)\right)\right.}}
$$

(Muhidin, S. A., \&

Keterangan:

$$
\text { Abdurrahman, M, 2011:31) }
$$

$\mathrm{r}_{\mathrm{xy}}$ : Koefisien korelasi antara variabel $\mathrm{X}$ dan variabel $\mathrm{Y}$

$\mathrm{N}$ : Jumlah siswa

$\sum X$ : Skor tiap butir soal

$\sum Y$ : Jumlah skor total tiap butir soal

Setelah data $r$ hitung pada tiap

butir pernyataan didapat kemudian dibandingkan dengan $r$ tabel, suatu instrumen dinyatakan valid jika nilai hitung $r$ lebih besar dibandingkan nilai tabel $\mathrm{r}$ ( $\mathrm{r}$ hitung $>\mathrm{r}$ tabel $=$ instrumen valid). Uji coba soal tes instalasi tenaga listrik siswa yang dilakukan terdiri dari 50 butir soal. Uji coba soal tes instalasi tenaga listrik dilakukan oleh 35 orang siswa kelas XII TL 2 SMKN 2 Kota
Serang pada tanggal 21 Oktober 2019. Hasil perhitungan uji validitas dengan memakai aplikasi Microsoft Excel didapatkan 24 soal yang valid.

\section{Uji Reliabilitas}

Reliabilitas merupakan tingkat keajegan suatu soal. Maksudnya, berapa kali pun alat penilaian dipakai bakal memberikan hasil relatif sama. Jadi uji reliabilitas instrumen dilakukan untuk mengetahui konsistensi dari instrumen untuk alat ukur sehingga bisa dipercaya (Jihad, 2012: 65).

Formula dalam menguji reliabilitas instrumen penelitian ini ialah Koefisien Alfa (á) dari Cronbach yang bisa dilihat pada rumus:

$$
\mathrm{r}_{11}=\left[\frac{k}{k-1}\right] \cdot\left[1-\frac{\sum \sigma_{i}^{2}}{\sigma_{t}^{2}}\right]
$$

Untuk mencari varians menggunakan rumus seperti di bawah ini:

$$
\sigma^{2}=\frac{\sum X^{2}-\frac{\left(\sum X\right)^{2}}{N}}{N}
$$

(Sugiyono, 2017: 365)

Keterangan:

$\mathrm{r}_{11}$ : Reliabilitas instrumen/koefisien alfa

$\mathrm{k} \quad$ : Banyaknya soal

$\sum \sigma_{i}^{2}:$ Jumlah varians skor tiap-tiap item

$\sigma_{t}^{2} \quad:$ Varians total

$N \quad$ : Jumlah responden

Kriterianya adalah dengan Kriterianya yakni membandingkan nilai $\mathrm{r}_{11}$ ke tabel harga kriteria $\mathrm{r}$ produk momen, dimana $r_{11}$ dikatakan signifikan jika $r 11>r_{\text {tabel }}$ taraf signifikan 5\%). Kategori derajat reliabilitas yakni:

Tabel 2. Kriteria Koefisien Cronbach Alpha

\begin{tabular}{ll}
\hline $\begin{array}{l}\text { Kriteria Koefisien } \\
\text { Cronbach Alpha }\end{array}$ & Keterangan \\
\hline $0,800-1,000$ & $\begin{array}{l}\text { Reliabilitas } \\
\text { sangat tinggi } \\
\text { Reliabilitas }\end{array}$
\end{tabular}




\begin{tabular}{ll}
\hline $\begin{array}{l}\text { Kriteria Koefisien } \\
\text { Cronbach Alpha }\end{array}$ & Keterangan \\
\hline & tinggi \\
$0,400-0,599$ & $\begin{array}{l}\text { Reliabilitas } \\
\text { sedang }\end{array}$ \\
$0,200-0,399$ & $\begin{array}{l}\text { Reliabilitas } \\
\text { rendah }\end{array}$ \\
$0,000-0,199$ & $\begin{array}{l}\text { Reliabilitas } \\
\text { sangat rendah }\end{array}$ \\
\hline
\end{tabular}

(Sumber: Arikunto, 2017: 89)

Uji instrument dilakukan terdiriatasi 50 butir soal tes hasil belajar siswa dengan materi sistem busbar dan saluran pelindung kabel. Uji reliabilitas dilakukan dengan Cronbach Alpha dan hasil yang telah didapatkan dianalisis. Nilai koefisien reliabilitas yang didapatkan adalah 0,920 masuk dalam kategori reliabilitas yang sangat tinggi. Berarti soal instrumen uji coba tes hasil belajar instalasi tenaga listrik siswa dapat dipercaya karena instrumen tersebut sudah sangat baik.

\section{Uji Normalitas Data}

Pada pengujian normalitas data ini yakni agar mendapatkan sebuah sampel dihasilkan berasal dari populasi berdistribusi normal atau tidak. Jika data penelitian berdistribusi normal pengujian bisa memakai teknik analisis parametrik, namun jika data tidak normal menggunakan teknik statistik non parametrik.

Peneliti menggunakan metode chi kuadrat, berikut rumus dari chi kuadrat tersebut:

$$
x^{2}=\sum_{i}^{k}=i \frac{\left(f_{0}-f_{h}\right)^{2}}{f_{h}}
$$

(Sugiyono, 2017: 107)

Keterangan:

$\mathrm{x}^{2}=$ Chi Kuadrat

$\mathrm{f}_{0}=$ frekuensi yang di observasi

$\mathrm{f}_{\mathrm{h}}=$ frekuensi yang diharapkan

Adapun kriteria uji normalitas data ialah: Jika $\mathrm{x}_{\text {hitung }}^{2}<\mathrm{x}_{\text {tabel }}^{2}$ maka data yang diperoleh berdistribusi normal. Jika $x_{\text {hitung }}^{2}>\mathrm{x}_{\text {tabel }}^{2}$ maka data yang diperoleh berdistribusi tidak normal.

\section{Uji Homogenitas Data}

Penelitian berdistribusi normal, langkah analisis data yang berikutnya yakni uji homogenitas. Uji homogenitas ialah pengujian mengenai sama tidaknya variansi dua buah distribusi atau lebih. Untuk menguji homogen data penelitian maka penelitian ini akan digunakan uji-F. Dengan rumus uji-F yang digunakan:

Dimana:

$$
\mathrm{F}=\frac{S_{1}^{2}}{S_{2}^{2}}
$$

$S_{1}^{2}=$ untuk varians yang besar, sebagai pembilang

$S_{2}^{2}=$ untuk varians yang kecil, sebagai penyebut

Adapun kriteria uji homogenitas data adalah: Jika $F_{\text {hitung }}<\mathrm{F}_{\text {tabel }}$ maka data yang diperoleh homogen. Jika $F_{\text {hitung }}>F_{\text {tabel }}$ maka data yang diperoleh tidak homogen.

\section{Uji Hipotesis}

Uji hipotesis menggunakan uji anova. Anova (analysis of varians) merupakan prosedur penggunaan untuk melihat variasi muncul adanya beberapa perlakuan sehingga bisa disimpulkan ada atau tidaknya perbedaan rataan populasi.

Analisis varians terbagi menjadi dua macam yakni analisis varians klasifikasi tunggal dan analisis varians klasifikasi ganda. Dalam penelitian ini menggunakan analisis varians klasifikasi tunggal, atau disebut anova satu jalur. Anova satu jalur digunakan dalam menguji hipotesis komparatif rata-rata $\mathrm{k}$ sampel (Sugiyono, 2017:165). Setiap sampel mempunyai Mean (rata-rata) dan Varians (simpangan baku kuadrat). 
Dikaitkan dengan penelitian ini uji anova satu jalur bertujuan dalam menguji ada atau tidaknya perbedaan efek yang signifikan antar perlakuan yang telah diberikan. Pengujian anova dilakukan pada program SPSS.

\section{Uji Effect Size}

Efektivitas model pembelajaran problem based learning dan model pembelajaran inquiry, dapat di uji memakai persamaan effect size. Effect size yakni besarnya efek suatu variabel pada variabel lain. Variabel sering terkait biasanya variabel independen dan variabel dependen (Saregar, Latifah, \& Sari, 2016: 236). Uji Effect Size dipakai seberapa besar efektivitas model pembelajaran Problem Based Learning dan Inquiry pada hasil belajar peserta didik. Rumus dari effect size adalah sebagai berikut:

$$
d=\frac{m_{A}-m_{B}}{\left[\left(s d_{A}^{2}+s d_{B}^{2}\right) / 2\right]^{1 / 2}}
$$

Keterangan:

(Saregar, Latifah, \& Sari, 2016)

$$
\mathrm{d} \quad=\text { Effect Size }
$$

$\mathrm{mA}=$ rata-rata Gain kelas eksperimen

$\mathrm{mB}$ = rata-rata Gain kelas kontrol

$S d_{A}=$ standar deviasi kelas eksperimen

$S d_{B}=$ standar deviasi kelas kontrol

Kriteria besar kecilnya effect size adalah sebagai berikut:

Tabel 3. Kriteria Effect Size

\begin{tabular}{ll}
\hline Effect Size & Kategori \\
\hline $\mathrm{d}<0,2$ & Kecil \\
$0,2<\mathrm{d}<0,8$ & Sedang \\
$\mathrm{d}>0,8$ & Tinggi \\
\hline
\end{tabular}

Setelah melakukan perhitungan uji effect size didapatkan hasil sebagai berikut:

Tabel 4. Hasil Uji Effect Size

\begin{tabular}{lllll}
\hline \multirow{3}{*}{ Kelas } & $\begin{array}{l}\text { Rata } \\
\text {-rata } \\
\text { Gain }\end{array}$ & $\begin{array}{l}\text { Standar } \\
\text { Deviasi }\end{array}$ & $\begin{array}{l}\text { Effect } \\
\text { Size }\end{array}$ & Kategori \\
\hline Eksperimen & 16,08 & 6,93 & 0,33 & Sedang
\end{tabular}

\begin{tabular}{lllll}
1 & 13,63 & 7,74 & & \\
Kontrol & 21,02 & 7,49 & & \\
Eksperimen & 21,97 & Tinggi \\
2 & 13,63 & 7,74 & & \\
Kontrol & & & \\
\hline
\end{tabular}

Tabel 4 nilai uji effect size kelas eksperimen 1, kelas eksperimen 2 dan kelas kontrol. Nilai uji effect size di kelas eksperimen 1 memakai model pembelajaran problem based learning yaitu 0,33 masuk dalam kategori sedang. Dilanjut nilai uji effect size di kelas eksperimen 2 memakai model pembelajaran inquiry yaitu 0,97 termasuk dalam kategori tinggi. Maka disimpulkan untuk model pembelajaran inquiry lebih efektif dalam meningkatkan hasil belajar siswa mata pelajaran instalasi tenaga listrik masuk kategori tinggi.

\section{HASIL DAN PEMBAHASAN}

Penelitian dilakukan di SMK PGRI 1 Kota Serang di kelas XII program keahlian Teknik Ketenagalistrikan yang memiliki 3 kelas sebagai sampel. Kelas XII TITL 1 sebagai kelas eksperimen diajarkan memakai model pembelajaran Problem Based Learning, kelas XII TITL 2 sebagai kelas eksperimen diajarkan memakai model pembelajaran Inquiry dan kelas XII TITL 3 sebagai kelas kontrol yang diajarkan memakai model pembelajaran konvensional.

Berikut deskripsi penelitian hasil perhitungan soal evaluasi siswa kelas eksperimen dan kelas kontrol. Data penelitian ini yakni data terkumpul pada hasil pretest dan posttest diberikan ke siswa kelas XII program keahlian Teknik Ketenagalistrikan di SMK PGRI 1 Kota Serang. 
a. Hasil Belajar ITL Siswa Kelas Eksperimen Problem Based Learning

Data pretest dan posttest hasil belajar Instalasi Tenaga Listrik siswa diberikan kepada kelas eksperimen model pembelajaran problem based learning adalah:

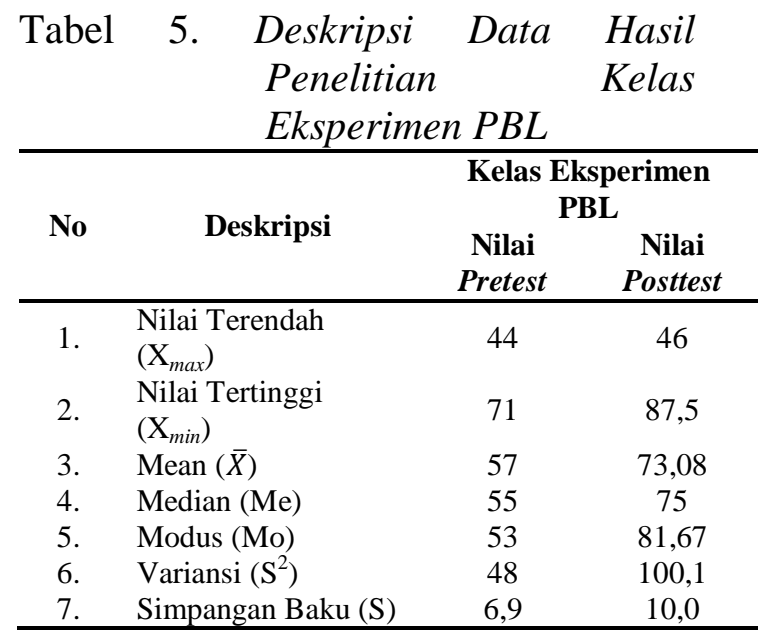

Tabel 5 bisa dilihat siswa kelas eksperimen problem based learning sebelum diberikan perlakuan mendapatkan nilai rata-rata 57. Nilai terbaik yang didapatkan siswa sebelum diberikan perlakuan kelas eksperimen problem based learning bernilai 71, lalu nilai terendah yang didapatkan siswa kelas eksperimen bernilai 44. Untuk nilai tengah (Median) pada data yang telah didapatkan kelas eksperimen bernilai 55 dan nilai sering muncul (Modus) adalah 53.

Namun, sesudah diberi perlakuan model pembelajaran problem based learning selama proses pembelajarannya, didapatkan nilai ratarata 73,08 . Nilai terbaik sesudah diberi perlakuan yang didapatkan siswa kelas eksperimen problem based learning bernilai 87,5 sedangkan nilai terendah yang didapatkan siswa kelas eksperimen tersebut bernilai 46. Untuk nilai tengah (Median) pada data yang telah diperoleh dari kelas eksperimen tersebut adalah 75 dan nilai sering muncul (Modus) adalah 81,67.

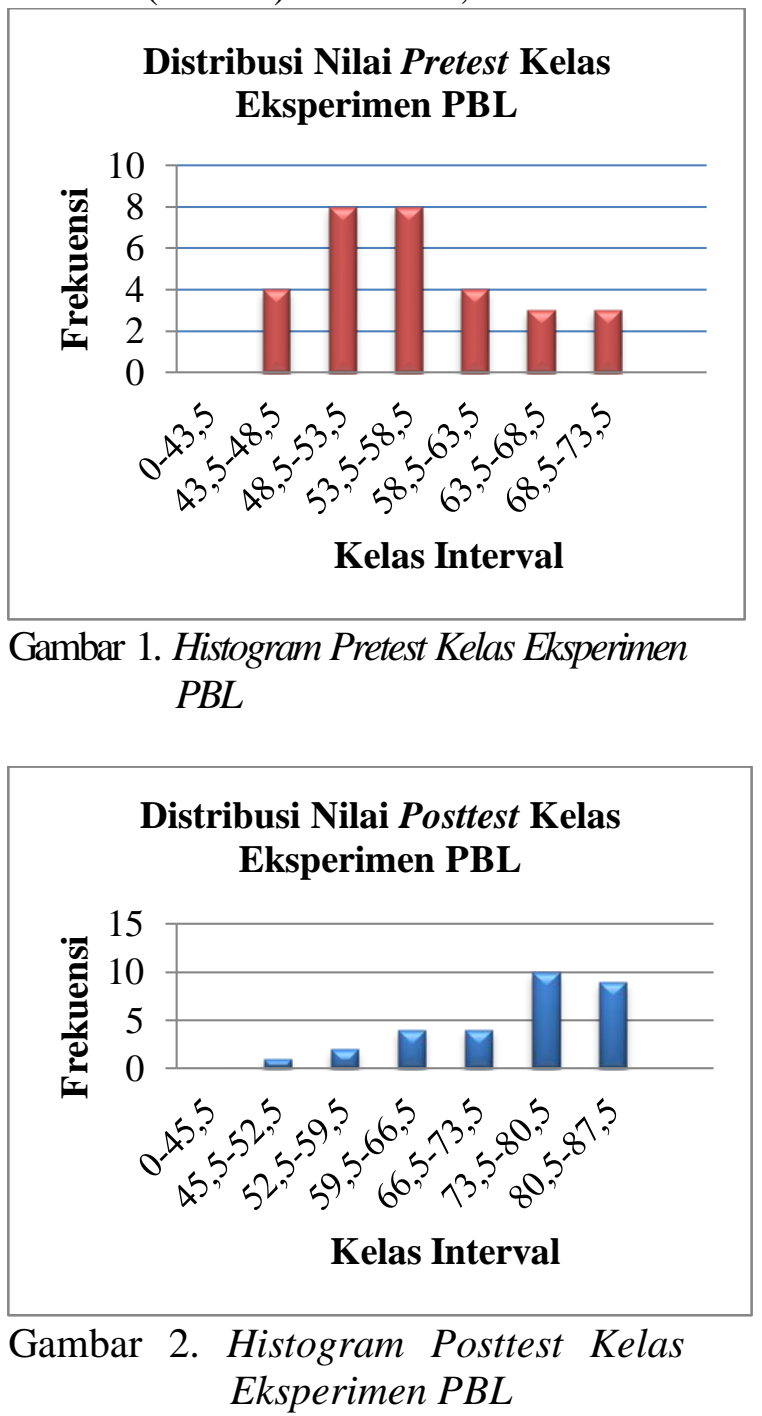

Berdasarkan gambar histogram hasil belajar instalasi tenaga listrik kelas eksperimen problem based learning seusai diberikan perlakuan memakai model pembelajaran problem based learning menunjukkan adanya peningkatan amat baik, hal itu dilihat terdapatnya siswa memperoleh nilai di atas KKM yakni 10 siswa.

\section{b. Hasil Belajar ITL Siswa Kelas Eksperimen Inquiry \\ Data pretest dan posttest hasil belajar Instalasi Tenaga Listrik siswa yang diberikan kepada kelas eksperimen}


dengan model pembelajaran Inquiry adalah:

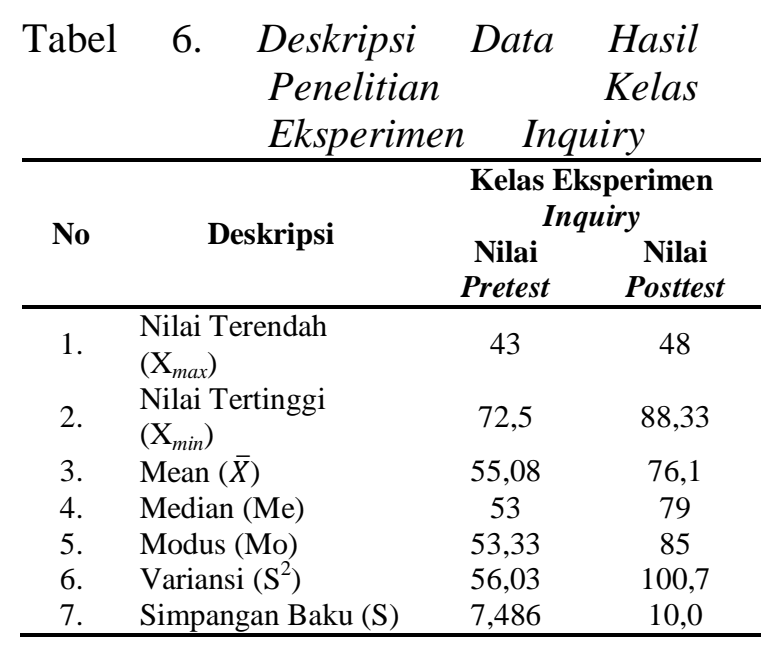

Tabel 6 bisa dilihat siswa kelas eksperimen Inquiry sebelum dikasih perlakuan mendapatkan nilai rata-rata 55,08. Nilai terbaik yang diperoleh siswa sebelum diberikan perlakuan kelas eksperimen Inquiry bernilai 72,5, sedangkan nilai terendah diperoleh siswa kelas eksperimen tersebut bernilai 43. Untuk nilai tengah (Median) pada data yang telah diperoleh dari kelas eksperimen bernilai 53 lalu nilai sering muncul (Modus) adalah 53,33.

Namun, setelah diberi perlakuan berupa penerapan model pembelajaran Inquiry selama proses pembelajarannya, diperoleh nilai rata-rata 76,1 . Nilai terbaik sesudah diberi perlakuan diperoleh siswa kelas eksperimen Inquiry bernilai 88,33 , sedangkan nilai terendah diperoleh siswa kelas eksperimen tersebut bernilai 48. Untuk nilai tengah (Median) pada data didapat kelas eksperimen tersebut bernilai 79 dan nilai sering muncul (Modus) bernilai 85 .
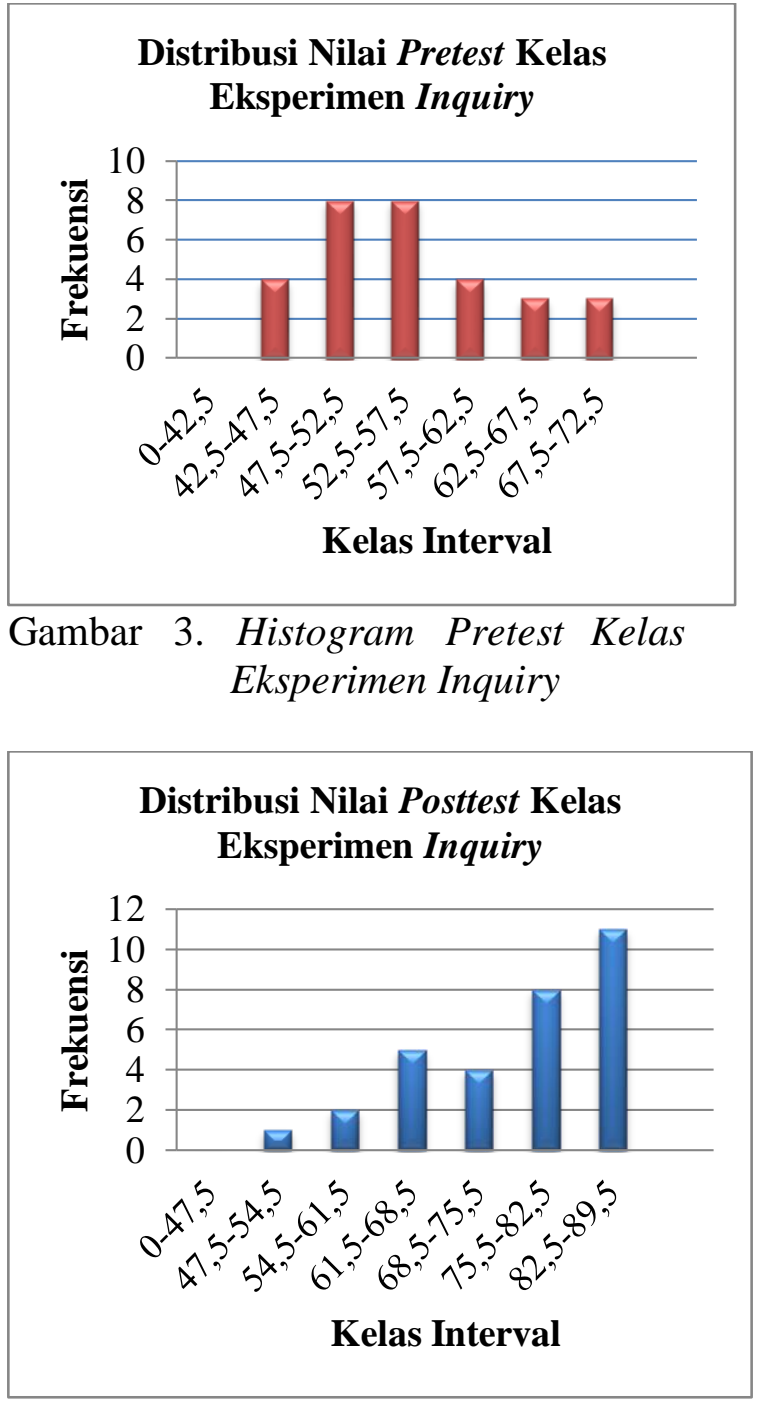

Gambar 4. Histogram Posttest Kelas Eksperimen Inquiry

Berdasarkan gambar histogram hasil belajar instalasi tenaga listrik kelas eksperimen inquiry seusai diberikan perlakuan menggunakan model pembelajaran inquiry menunjukkan adanya peningkatan baik, hal itu bisa dilihat terdapatnya siswa memperoleh nilai di atas KKM yakni 18 siswa.

\section{c. Hasil Belajar ITL Siswa Kelas Kontrol}

Data pretest dan posttest hasil belajar Instalasi Tenaga Listrik siswa diberikan ke kelas kontrol adalah: 
Tabel 7. Deskripsi Data Hasil

\begin{tabular}{|c|c|c|c|}
\hline \multirow[b]{3}{*}{ No. } & \multirow[b]{3}{*}{ Deskripsi } & \multirow{2}{*}{\multicolumn{2}{|c|}{$\begin{array}{l}\text { Kelas Kontrol } \\
\text { Kelas Kontrol }\end{array}$}} \\
\hline & & & \\
\hline & & $\begin{array}{c}\text { Nilai } \\
\text { Pretest }\end{array}$ & $\begin{array}{c}\text { Nilai } \\
\text { Posttest }\end{array}$ \\
\hline 1. & $\begin{array}{l}\text { Nilai Terendah } \\
\left(\mathrm{X}_{\max }\right)\end{array}$ & 40 & 41 \\
\hline 2. & $\begin{array}{l}\text { Nilai Tertinggi } \\
\left(\mathrm{X}_{\min }\right)\end{array}$ & 68,3 & 80 \\
\hline 3. & $\operatorname{Mean}(\bar{X})$ & 54,3 & 67,93 \\
\hline 4. & Median (Me) & 54 & 69 \\
\hline 5. & Modus (Mo) & 56,7 & 80 \\
\hline 6. & Variansi $\left(\mathrm{S}^{2}\right)$ & 59,9 & 113,5 \\
\hline 7. & $\begin{array}{l}\text { Simpangan Baku } \\
\text { (S) }\end{array}$ & 7,74 & 10,7 \\
\hline
\end{tabular}

Tabel 7 bisa dilihat siswa kelas kontrol sebelum diberi perlakuan mendapatkan nilai rata-rata 54,3. Nilai terbaik yang diperoleh siswa sebelum diberikan perlakuan kelas kontrol tersebut bernilai 68,3 sedang nilai terendah diperoleh siswa kelas kontrol bernilai 40. Untuk nilai tengah (Median) pada data telah didapatkan dari kelas kontrol bernilai 54 dan nilai yang sering muncul (Modus) adalah 56,7 .

Namun, setelah diberi perlakuan berupa penerapan model pembelajaran konvensional selama proses pembelajarannya, diperoleh skor nilai rata-rata 67,93. Nilai terbaik diperoleh siswa kelas kontrol sesudah diberi perlakuan bernilai 80 , sedangkan nilai terendah yang diperoleh siswa kelas kontrol tersebut bernilai 41. Untuk nilai tengah (Median) pada data telah diperoleh dari kelas kontrol bernilai 69 dan nilai sering muncul (Modus) adalah 80.
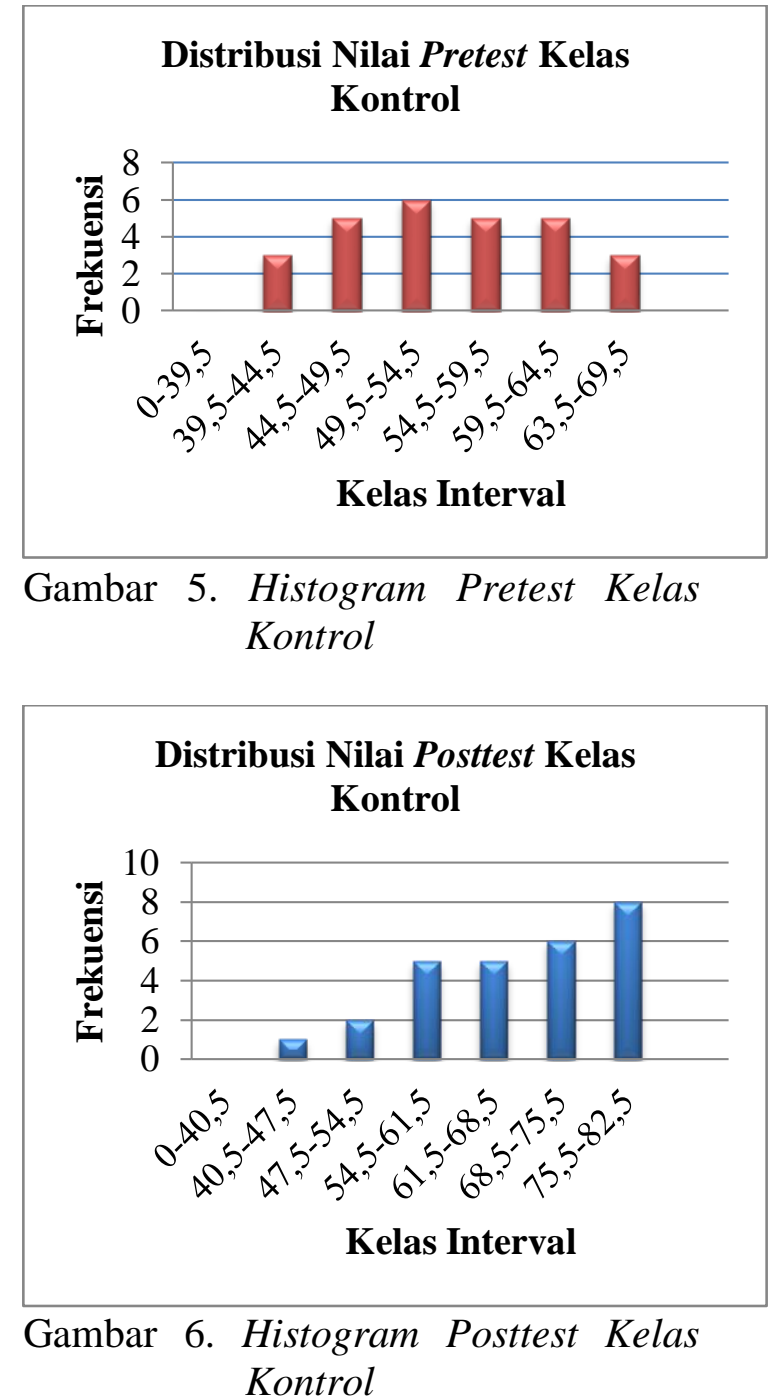

Dari gambar histogram tersebut bisa dilihat hasil belajar instalasi tenaga listrik kelas kontrol setelah diberi perlakuan memakai model pembelajaran konvensional menunjukkan bahwa masih banyak siswa mendapat nilai di bawah KKM dibandingkan dengan siswa mendapat nilai di atas KKM. Hal itu bisa dilihat terdapatnya siswa memperoleh nilai di atas KKM yaitu 6 siswa.

Perbedaan hasil belajar instalasi tenaga listrik antara kelas eksperimen dan kelas kontrol, lihat di tabel: 
Tabel 8. Perbandingan Hasil Belajar ITL Kelas Eksperimen dan Kelas Kontrol

\begin{tabular}{|c|c|c|c|c|c|c|c|}
\hline \multirow{2}{*}{$\begin{array}{l}\mathbf{N} \\
\mathbf{0}\end{array}$} & \multirow{2}{*}{$\begin{array}{l}\text { Desk } \\
\text { ripsi }\end{array}$} & \multicolumn{2}{|c|}{$\begin{array}{c}\text { Kelas } \\
\text { Eksperim } \\
\text { en PBL }\end{array}$} & \multicolumn{2}{|c|}{$\begin{array}{c}\text { Kelas } \\
\text { Eksperim } \\
\text { en Inquiry }\end{array}$} & \multicolumn{2}{|c|}{$\begin{array}{c}\text { Kelas } \\
\text { Kontrol }\end{array}$} \\
\hline & & $\begin{array}{l}\text { Pre } \\
\text { test }\end{array}$ & $\begin{array}{l}\text { Pos } \\
\text { ttest }\end{array}$ & $\begin{array}{l}\text { Pre } \\
\text { test }\end{array}$ & $\begin{array}{l}\text { Pos } \\
\text { ttest }\end{array}$ & $\begin{array}{l}\text { Pre } \\
\text { test }\end{array}$ & $\begin{array}{l}\text { Pos } \\
\text { ttest }\end{array}$ \\
\hline 1 & $\begin{array}{l}\text { Nilai } \\
\text { Tere } \\
\text { ndah } \\
\left(\mathrm{X}_{\max }\right. \\
)^{\text {Nilai }}\end{array}$ & 44 & 46 & 43 & 48 & 40 & 41 \\
\hline 2 & $\begin{array}{l}\text { Terti } \\
\text { nggi } \\
\left(\mathrm{X}_{\min }\right. \\
)\end{array}$ & 71 & 87,5 & $\begin{array}{c}72 \\
5\end{array}$ & $\begin{array}{c}88,3 \\
3\end{array}$ & $\begin{array}{c}68 \\
3\end{array}$ & 80 \\
\hline 3 & $\begin{array}{l}\text { Mea } \\
\mathrm{n}(\bar{X})\end{array}$ & 57 & $\begin{array}{c}73,0 \\
8\end{array}$ & $\begin{array}{c}55 \\
08\end{array}$ & 76,1 & $\begin{array}{c}54, \\
3\end{array}$ & $\begin{array}{c}67,9 \\
3\end{array}$ \\
\hline 4 & $\begin{array}{l}\text { Medi } \\
\text { an } \\
(\mathrm{Me})\end{array}$ & 55 & 75 & 53 & 79 & 54 & 69 \\
\hline 5 & $\begin{array}{l}\text { Mod } \\
\text { us } \\
\text { (Mo) }\end{array}$ & 53 & $\begin{array}{c}81,6 \\
7\end{array}$ & $\begin{array}{l}53, \\
33\end{array}$ & 85 & $\begin{array}{c}56 \\
7\end{array}$ & 80 \\
\hline 6 & $\begin{array}{l}\text { Vari } \\
\text { ansi } \\
\left(\mathrm{S}^{2}\right)\end{array}$ & 48 & $\begin{array}{c}100, \\
1\end{array}$ & $\begin{array}{l}56, \\
03\end{array}$ & $\begin{array}{c}100 \\
7\end{array}$ & $\begin{array}{c}59 \\
9\end{array}$ & $\begin{array}{c}113, \\
5\end{array}$ \\
\hline 7 & $\begin{array}{l}\text { Simp } \\
\text { anga } \\
\mathrm{n} \\
\text { Baku } \\
\text { (S) }\end{array}$ & 6,9 & 10,0 & $\begin{array}{l}7,4 \\
86\end{array}$ & 10,0 & $\begin{array}{c}7,7 \\
4\end{array}$ & 10,7 \\
\hline
\end{tabular}

Dari data Tabel 8 terlihat perbedaan hasil belajar Instalasi Tenaga Listrik siswa kelas eksperimen dan kelas kontrol. Perbedaan tersebut bisa dilihat nilai rata-rata antara kelas eksperimen dan kelas kontrol dimana kelas eksperimen lebih tinggi dibandingkan dengan kelas kontrol.

Hasil belajar Instalasi Tenaga Listrik siswa pada pokok bahasan sistem busbar dan saluran pelindung kabel kelas eksperimen dan kelas kontrol memiliki perbedaan nilai ratarata hasil belajar kognitif siswa menggunakan model pembelajaran problem based learning dan inquiry hasil belajar siswa menggunakan model pembelajaran konvensional.

\section{Uji Normalitas Data}

Uji normalitas dilakukan untuk pengujian normal atau tidak sebaran data analisis (Sugiyono, 2017: 107). Jika $\boldsymbol{x}_{\text {hitung }}<\boldsymbol{x}^{\mathbf{2}}{ }_{\text {tabel }}$ maka data yang diperoleh berdistribusi normal. Jika $\boldsymbol{x}_{\text {hitung }}>\boldsymbol{x}_{\text {tabel }}{ }_{\text {taba }}$ maka data yang diperoleh berdistribusi tidak normal.

Hasil uji normalitas pada ketiga kelas penelitian menggunakan Chi Kuadrat dengan taraf signifikansi 5\% dapat dilihat pada tabel berikut.

Tabel 9. Uji Normalitas Data

\begin{tabular}{|c|c|c|c|c|}
\hline Kelas & & $x^{2}$ hitur & $\begin{array}{l}x^{2} \text { tabel } \\
\alpha \\
=0,05\end{array}$ & Kesimpulan \\
\hline \multirow{4}{*}{$\begin{array}{l}\text { Eksperimen } \\
\text { PBL }\end{array}$} & Pretes & 4,14 & \multirow{2}{*}{11,070} & \multirow{2}{*}{$\begin{array}{l}\text { Berdistribusi } \\
\text { normal }\end{array}$} \\
\hline & $t$ & 5 & & \\
\hline & Postte & 6,50 & 11070 & Berdistribusi \\
\hline & $s t$ & 4 & $11,0 / 0$ & normal \\
\hline \multirow{4}{*}{$\begin{array}{l}\text { Eksperimen } \\
\text { Inquiry }\end{array}$} & Pretes & 4,34 & \multirow{2}{*}{11,070} & \multirow{2}{*}{$\begin{array}{l}\text { Berdistribusi } \\
\text { normal }\end{array}$} \\
\hline & $t$ & 9 & & \\
\hline & Postte & 8,69 & 11,070 & Berdistribusi \\
\hline & $s t$ & 4 & & normal \\
\hline \multirow{4}{*}{ Kontrol } & Pretes & 1,70 & \multirow{2}{*}{11,070} & \multirow{4}{*}{$\begin{array}{l}\text { Berdistribusi } \\
\text { normal } \\
\text { Berdistribusi } \\
\text { normal }\end{array}$} \\
\hline & $t$ & 1 & & \\
\hline & Postte & 4,99 & 11.070 & \\
\hline & $s t$ & 6 & & \\
\hline
\end{tabular}

Tabel 9 hasil uji normalitas data kelas eksperimen dan kelas kontrol. Hasil uji normalitas tersebut menunjukkan bahwa data pada kelas eksperimen dan kelas kontrol berdistribusi normal, ketika data sudah mempunyai asumsi berdistribusi normal maka analisis statistis yang digunakan adalah analisis statistik parametris

Hasil uji pretest kelas eksperimen problem based learning didapatkan nilai $x^{2}$ hitung $=4,145$. Sedangkan uji chi kuadrat didapat nilai $x^{2}$ tabel pada derajat kebebasan (dk) ialah 5 pada taraf signifikan $\alpha=0,05$ yakni 11,070 . Karena $x^{2}$ hitung kurang dari $x^{2}$ tabel $(4,145$ $<$ 11,070) maka $\mathrm{H}_{0}$ diterima, data pretest kelas eksperimen problem based learning berasal populasi berdistribusi normal. 
Selanjutnya hasil uji posttest kelas eksperimen problem based learning didapatkan nilai $x^{2}{ }_{\text {hitung }}=6,504$. Sedangkan uji chi kuadrat didapat nilai $x^{2}$ tabel dengan derajat kebebasan (dk) ialah 5 pada taraf signifikan $\alpha=0,05$ yakni 11,070 . Karena $x^{2}$ hitung kurang dari $x_{\text {tabel }}^{2}(6,504<11,070)$ maka $\mathrm{H}_{0}$ diterima, data posttest kelas eksperimen problem based learning berasal populasi berdistribusi normal.

Kemudian hasil uji pretest kelas eksperimen inquiry diperoleh nilai $x^{2}$ hitung $=4,349$. Sedangkan uji chi kuadrat didapat nilai $x^{2}$ tabel dengan derajat kebebasan (dk) ialah 5 pada taraf signifikan $\alpha=0,05$ yakni 11,070. Karena $x^{2}$ hitung kurang dari $x^{2}$ tabel $(4,349$ $<$ 11,070) maka $\mathrm{H}_{0}$ diterima, data pretest kelas eksperimen inquiry berasal populasi berdistribusi normal.

Pada uji posttest kelas eksperimen inquiry didapat nilai $x^{2}$ hitung $=8,694$. Sedangkan uji chi kuadrat didapat nilai $x^{2}$ tabel dengan derajat kebebasan (dk) ialah 5 pada taraf signifikan $\alpha=0,05$ yakni 11,070 . Karena $x^{2}$ hitung kurang dari $x_{\text {tabel }}^{2}(8,694<11,070)$ maka $\mathrm{H}_{0}$ diterima, data posttest kelas eksperimen inquiry berasal populasi berdistribusi normal.

Selanjutnya uji pretest kelas kontrol diperoleh nilai $x^{2}{ }_{\text {hitung }}=1,701$. Sedangkan uji chi kuadrat didapat nilai $x^{2}$ tabel dengan derajat kebebasan (dk) ialah 5 pada taraf signifikan $\alpha=0,05$ yakni 11,070 . Karena $x^{2}$ hitung kurang dari $x_{\text {tabel }}^{2}(1,701<11,070)$ maka $\mathrm{H}_{0}$ diterima, data pretest kelas kontrol berasal populasi berdistribusi normal.

Pada uji posttest kelas kontrol diperoleh nilai $x^{2}{ }_{\text {hitung }}=4,996$. Sedangkan uji chi kuadrat didapat nilai $x^{2}$ tabel dengan derajat kebebasan (dk) ialah 5 pada taraf signifikan $\alpha=0,05$ yakni 11,070 . Karena $x^{2}$ hitung kurang dari $x_{\text {tabel }}^{2}(4,996<11,070)$ maka $\mathrm{H}_{0}$ diterima, data posttest kelas kontrol berasal populasi berdistribusi normal.

\section{Uji Homogenitas Data}

Seusai ketiga kelas sampel dinyatakan berdistribusi normal, dilakukan uji homogenitas varians. Uji homogenitas dilakukan menguji kesamaan varians distribusi normal. Data dikatakan homogen jika data kelompok eksperimen dan kelompok kontrol mempunyai variansi pada homogen (Muhidin \& Abdurrahman, 2011: 84). Untuk dapat menguji homogenitas maka digunakan Uji Fisher. Hasil uji homogenitas pada kelas eksperimen dan kelas kontrol Tabel 10.

\section{Tabel 10. Uji Homogenitas Data}

\begin{tabular}{|c|c|c|c|c|}
\hline Kelas & Data & $\mathbf{F}_{\text {hitung }}$ & $\mathbf{F}_{\text {tabel }}$ & Kesimpulan \\
\hline $\begin{array}{l}\text { Eksperim } \\
\text { en } 1\end{array}$ & Pretest & 1,247 & 1,766 & $\begin{array}{c}\text { Data } \\
\text { Homogen }\end{array}$ \\
\hline Kontrol & Posttest & 1,133 & 1,766 & $\begin{array}{c}\text { Data } \\
\text { Homogen }\end{array}$ \\
\hline $\begin{array}{l}\text { Eksperim } \\
\text { en } 2\end{array}$ & Pretest & 1,014 & 1,766 & $\begin{array}{c}\text { Data } \\
\text { Homogen }\end{array}$ \\
\hline Kontrol & Posttest & 1,127 & 1,766 & $\begin{array}{c}\text { Data } \\
\text { Homogen }\end{array}$ \\
\hline
\end{tabular}

Hasil perhitungan uji homogenitas pretest kelas eksperimen 1 dan kelas kontrol diperoleh nilai $F_{\text {hitung }}=1,247$ dan $F_{\text {tabel }}=1,766$. Karena $F_{\text {hitung dari }}$ pretest kelas eksperimen 1 dan kelas kontrol kurang dari $\mathrm{F}_{\text {tabel }}(1,247<1,766)$ maka $\mathrm{H}_{0}$ diterima, artinya bahwa kedua kelompok sampel tersebut terdapat varians sama atau homogen. Sedangkan untuk perhitungan uji homogenitas pretest kelas eksperimen 2 dan kelas kontrol diperoleh nilai $F_{\text {hitung }}=1,014$ dan $F_{\text {tabel }}=1,766$. Karena $F_{\text {hitung dari }}$ pretest kelas eksperimen 2 dan kelas kontrol kurang dari $F_{\text {tabel }}(1,014<1,766)$ maka $\mathrm{H}_{0}$ diterima, artinya kedua kelompok sampel tersebut memiliki varians sama atau homogen.

Kemudian dari hasil perhitungan uji homogenitas posttest kelas eksperimen 
1 dan kelas kontrol diperoleh nilai $F_{\text {hitung }}$ $=1,133$ dan $F_{\text {tabel }}=1,766$. Karena $F_{\text {hitung }}$ dari posttest kelas eksperimen dan kelas kontrol kurang dari $\mathrm{F}_{\text {tabel }}(1,133<1,766)$ maka $\mathrm{H}_{0}$ diterima, artinya kedua kelompok sampel terdapat varians sama atau homogen. Sedangkan dari hasil perhitungan uji homogenitas posttest kelas eksperimen 2 dan kelas kontrol diperoleh nilai $\mathrm{F}_{\text {hitung }}=1,127$ dan $\mathrm{F}_{\text {tabel }}=$ 1,766. Karena $F_{\text {hitung }}$ dari posttest kelas eksperimen dan kelas kontrol kurang dari $\mathrm{F}_{\text {tabel }} \quad(1,127<1,766)$ maka $\mathrm{H}_{0}$ diterima, artinya kedua kelompok sampel memiliki varians sama atau homogen.

Dari hasil perhitungan uji homogenitas pada tabel di atas bisa disimpulkan data dari hasil penelitian kelas eksperimen dan kelas kontrol mempunyai nilai varian sama (homogen). Setelah diketahui data penelitian mempunyai nilai varian yang sama maka selanjutnya data tersebut dapat dianalisis menggunakan analisis statistik parametris. Analisis statistik parametris adalah uji anova satu jalur.

\section{Hasil Uji Hipotesis}

Ketika semua data memenuhi uji prasyarat analisis yaitu berdistribusi normal dan homogen, dilakukan pengujian hipotesis. Pengujian dilakukan mengetahui rata-rata tes hasil belajar siswa mengalami perbedaan kelas eksperimen dan kelas kontrol antara keadaan sebelum perlakuan kemudian sesudah perlakuan memakai model pembelajaran problem based learning, inquiry, dan konvensional. Pengujian hipotesis dilakukan uji Anova satu jalur (Sugiyono, 2017: 165).

Berikut hasil perhitungan uji hipotesis menggunakan uji anova satu jalur menggunakan aplikasi SPSS 21 (Sarwono, 2015: 158). Hasil dari pengujian pada tabel:
Tabel 11. Pengujian Hipotesis ANOVA

Tes Hasil Belajar Posttest
\begin{tabular}{|l|r|r|r|r|r|}
\hline & \multicolumn{1}{|c|}{$\begin{array}{c}\text { Sum of } \\
\text { Squares }\end{array}$} & \multicolumn{1}{c|}{ df } & Mean Square & F & Sig. \\
\hline Between Groups & 974,042 & 2 & 487,021 & 4,660 &, 012 \\
Within Groups & 8883,722 & 85 & 104,514 & & \\
Total & 9857,763 & 87 & & & \\
\hline
\end{tabular}

Terlihat harga $\mathrm{F}$ hitung sebesar 4,660. Harga tersebut kemudian dibandingkan harga $\mathrm{F}$ tabel dengan df pembilang $=\mathrm{m}-1$ dan $\mathrm{df}$ penyebut $=\mathrm{N}$ $\mathrm{m}$. Demikian df pembilang $=3-1=2$ dan df penyebut $=88-3=85$. Berdasarkan dua df tersebut, diketahui harga $\mathrm{F}$ tabel untuk 5\% =3,11. Harga $\mathrm{F}$ hitung 4,660 lebih besar dari $F$ tabel $(4,660>3,11)$. Karena harga $F$ hitung jauh lebih besar dari harga $F$ tabel hipotesis nol $\left(\mathrm{H}_{0}\right)$ diajukan ditolak dan $\mathrm{H}_{1}$ diterima. Kemudian pada kolom nilai sig didapatkan hasil sig. sebesar 0,012. Karena nilai sig $<0,05$ maka perbedaan efektivitas tes hasil belajar siswa signifikan antara model pembelajaran problem based learning, inquiry, dan konvensional.

Setelah diketahui bahwa hipotesis alternatifnya diterima maka harus dilakukan uji lanjut yaitu post hoc tests. Post hoc test merupakan uji lanjut yang didalamnya terdapat uji tukey. Uji tukey dilakukan mengetahui kelompok mana saja berbeda.

Tabel 12. Hasil Uji Tukey

\begin{tabular}{|c|c|c|c|c|}
\hline $\begin{array}{c}\text { (I) } \\
\text { Model } \\
\text { Pembel } \\
\text { ajaran }\end{array}$ & $\begin{array}{c}\text { (J) Model } \\
\text { Pembelajar } \\
\text { an }\end{array}$ & $\begin{array}{c}\text { Mean } \\
\text { Differenc } \\
\text { e (I-J) }\end{array}$ & $\begin{array}{l}\text { Std. } \\
\text { Error }\end{array}$ & Sig \\
\hline $\begin{array}{l}\text { Problem } \\
\text { Based }\end{array}$ & Inquiry & $-3,007$ & 2,618 & $\begin{array}{c}0,00 \\
0\end{array}$ \\
\hline $\begin{array}{l}\text { Learnin } \\
g\end{array}$ & $\begin{array}{l}\text { Konvension } \\
\text { al }\end{array}$ & 5,156 & 2,712 & $\begin{array}{c}0,00 \\
0\end{array}$ \\
\hline Inquiry & $\begin{array}{l}\text { Problem } \\
\text { Based } \\
\text { Learning }\end{array}$ & 3,007 & 2,618 & $\begin{array}{c}0,00 \\
0\end{array}$ \\
\hline & $\begin{array}{l}\text { Konvension } \\
\text { al }\end{array}$ & 8,163 & 2,691 & $\begin{array}{c}0,00 \\
0\end{array}$ \\
\hline \multirow{2}{*}{$\begin{array}{l}\text { Konven } \\
\text { sional }\end{array}$} & $\begin{array}{l}\text { Problem } \\
\text { Based } \\
\text { Learning }\end{array}$ & $-5,156$ & 2,712 & $\begin{array}{c}0,00 \\
0\end{array}$ \\
\hline & Inquiry & $-8,163$ & 2,691 & $\begin{array}{c}0,00 \\
0\end{array}$ \\
\hline
\end{tabular}


Untuk mengetahui kelompok mana saja mempunyai tes hasil belajar lebih besar dapat dilihat pada kolom Mean Difference. ketika nilai pada Mean Difference berupa nilai negatif maka dapat dipastikan kolom $\mathbf{J}$ memiliki nilai yang lebih besar dibandingkan kolom I. Tabel diatas diketahui pada kolom $\mathbf{J}$ nilai Mean Difference untuk model Inquiry adalah -3,007, model konvensional adalah 5,156 dan model problem based learning ialah 3,007 artinya model pembelajaran Iquiry lebih besar nilai keefektivitasannya dibanding model problem based learning dan konvensional. Kemudian hasil dari uji hipotesis:

1. Hipotesis:

$\mathrm{H}_{0}: \mu_{1} \leq \mu_{3}$ (Model pembelajaran problem based learning tidak memberikan hasil belajar instalasi tenaga listrik yang efektif dari pada model konvensional).

$\mathrm{H}_{1}: \mu_{1}>\mu_{3}$ (Model pembelajaran problem based learning memberikan hasil belajar instalasi tenaga listrik yang efektif dari pada model konvensional).

a. Dasar pengambilan keputusan:

Jika Sig. > 0,05, maka $\mathrm{H}_{0}$ diterima

Jika Sig. $<0,05$, maka $\mathrm{H}_{0}$ ditolak

b. Keputusan:

Output terlihat nilai Sig. $<0,05$ maka $\mathrm{H}_{0}$ ditolak berarti model pembelajaran problem based learning memberikan hasil belajar instalasi tenaga listrik yang efektif dari pada model konvensional.

2. Hipotesis:

$\mathrm{H}_{0}: \mu_{2} \leq \mu_{3}$ (Model pembelajaran inquiry tidak memberikan hasil belajar instalasi tenaga listrik yang efektif dari pada model konvensional).

$\mathrm{H}_{1}: \mu_{2} \leq \mu_{3}$ (Model pembelajaran inquiry memberikan hasil belajar instalasi tenaga listrik yang efektif dari pada model konvensional).

a. Dasar pengambilan keputusan: Jika Sig. > 0,05, maka $\mathrm{H}_{0}$ diterima

Jika Sig. $<0,05$, maka $\mathrm{H}_{0}$ ditolak

b. Keputusan:

Output terlihat nilai Sig. $<0,05$ maka $\mathrm{H}_{0}$ ditolak berarti model pembelajaran inquiry memberikan hasil belajar instalasi tenaga listrik yang efektif dari pada model konvensional.

3. $\mathrm{H}_{0}: \mu_{1}=\mu_{2}=\mu_{3}$ Tidak ada perbedaan efektivitas model pembelajaran problem based learning dan inquiry dengan model konvensional terhadap hasilbelajar siswa.

$\mathrm{H}_{1}: \mu_{1} \neq \mu_{2} \neq \mu_{3}$ Ada perbedaan efektivitas model pembelajaran problem based learning dan inquiry dengan model konvensional terhadap hasil belajar siswa.

a. Dasar pengambilan keputusan:

Jika Sig. >0,05, maka $\mathrm{H}_{0}$ diterima

Jika Sig. $<0,05$, maka $\mathrm{H}_{0}$ ditolak b. Keputusan:

Output terlihat nilai Sig. $<0,05$ maka $\mathrm{H}_{0}$ ditolak berarti ada perbedaan efektivitas model pembelajaran problem based learning dan inquiry dengan model konvensional pada hasil belajar siswa.

\section{KESIMPULAN}

Simpulan diambil berdasarkan hasil penelitian yang telah peneliti lakukan tentang efektivitas model pembelajaran problem based learning dan inquiry terhadap hasil belajar instalasi tenaga listrik di SMK PGRI 1 Kota Serang maka disimpulkan: 
1. Model pembelajaran Problem Based Learning lebih efektif dibanding model pembelajaran konvensional terhadap hasil belajar instalasi tenaga listrik siswa. Hal itu dibuktikan melihat hasil pretest dan posttest, yakni pretest nilai rata-rata sebesar 57 dan posttest nilai rata-rata sebesar 73,08 . Dengan hasil uji hipotesis seusai perlakuan didapatkan nilai taraf signifikan $\alpha=0,05$ sehingga $\mathrm{H}_{1}$ diterima lalu hasil dari effect size yang didapatkan sebesar 0,33 ;

2. Model pembelajaran Inquiry lebih efektif dibanding model pembelajaran konvensional terhadap hasil belajar instalasi tenaga listrik siswa. Hal itu dibuktikan melihat hasil pretest dan posttest, yakni pretest nilai rata-rata sebesar 55,08 dan posttest nilai rata-rata sebesar 76,1. Dengan hasil uji hipotesis seusai perlakuan didapatkan nilai taraf signifikan $\alpha=$ 0,05 sehingga $\mathrm{H}_{1}$ diterima lalu hasil dari effect size yang didapatkan sebesar 0,97;

3. Ada perbedaan efektivitas model pembelajaran Problem Based Learning dan Inquiry dengan model pembelajaran konvensional terhadap hasil belajar instalasi tenaga listrik siswa. Hal tersebut dibuktikan dengan melihat hasil uji anova satu jalur dimana harga $F$ hitung lebih besar pada $\mathrm{F}$ tabel $(4,660>3,11)$ sehingga $\mathrm{H}_{1}$ diterima. Pada kolom nilai sig didapatkan sebesar 0,012. Pada nilai sig $<0,05$ terdapat perbedaan efektivitas tes hasil belajar siswa signifikan antara model pembelajaran problem based learning, inquiry dan konvensional.

\section{DAFTAR PUSTAKA}

Arikunto, S. 2017. Manajemen Penelitian. Jakarta: Rineka Cipta.

Awal, R., \& Pardede, I. S. 2017. Pembelajaran Berbasis Masalah melalui Keterampilan Proses Sains terhadap Berpikir Kreatif Siswa pada Materi Sistem Gerak Kelas XI IPA 2 T.A 2015/2016 SMA Nurul Falah Pekanbaru. Jurnal Pendidikan Lectura, Vol. 8 No.2: 66-74.

Awg Kitot, A. K., Ahmad, A. R., \& Seman, A. A. (2011). The Effectiveness of Inquiry Teaching in Enhancing Students' Critical Thinking. Procedia Social and Behavioral Sciences, 7, 264-273.

Jihad, A., \& Abdul, H. 2012. Evaluasi Pembelajaran. Yogyakarta: Multi Presindo.

Lahir, S., Ma'ruf, M. H., \& Tho'in, M. (2017, Februari). Peningkatan Prestasi Belajar Melalui Model Pembelajaran yang Tepat pada Sekolah Dasar Sampai Perguruan Tinggi. Edunomika, 1,1 .

Lefrida, R. (2011). Efektifitas Penerapan Pembelajaran Kontekstual dengan Strategi REACT (Relating, Experiencing, Applying, Cooperating, dan Transferring) untuk Meningkatkan Pemahaman pada materi Logika Fuzzy. MIPA FKIP UNTAD, 36.

Muhidin, S. A., \& Abdurrahman, M. 2011. Analisis Korelasi, Regresi, 
dan Jalur dalam Penelitian. Bandung: CV Pustaka Setia.

Purwanto. 2014. Evaluasi Hasil Belajar. Yogyakarta: Pustaka Pelajar.

Rusman. 2017. Belajar dan Pembelajaran Berorientasi Standar Proses Pendidikan. Jakarta: Kencana.

Rusman. 2016. Model-Model Pembelajaran. Jakarta: PT Raja Grafindo Persada.

Saregar, A., Latifah, S., \& Sari, M. 2016. Efektivitas Model Pembelajaran CUPs: Dampak terhadap Kemampuan Berpikir Tingkat Tinggi Peserta Didik Madrasah Aliyah Mathla' ul Anwar Gisting Lampung. Jurnal Ilmiah Pendidikan Fisika AlBiRuNi, 5, 236

Sarwono, J. 2015. Rumus-Rumus Populer dalam SPSS 22 Untuk Riset Skripsi. Yogyakarta: ANDI Yogyakarta.

Shoimin, A. 2014. 68 Model Pembelajaran Inovatif dalam Kurikulum 2013. Yogyakarta: Ar-Ruzz Media.

Sudjana. 2017. Metode Statistik. Jakarta: Rineka Cipta.

Sudjana, N. 2017. Penilaian Hasil Proses Belajar Mengajar. Bandung: PT. Remaja Rosdakarya.

Sugiyono. 2015. Metode Penelitian Pendidikan. Bandung: Alfabeta.

Sugiyono. 2017. Statistika Untuk Penelitian. Bandung: Alfabeta.
Sund, R. B., \& Trowbridge, L. W. (1973). Teaching Science by Inquiry in the Secondary School. Ohio: A Bell \& Howell Company.

Zuliana, E. 2017. Penerapan Inquiry Based Learning berbantuan Peraga Manipulatif dalam Meningkatkan Pemahaman Konsep Matematika pada Materi Geometri Mahasiswa PGSD Universitas Muria Kudus. Jurnal Pendidikan Lectura, Vol. 8 No.1: 35-43. 